\title{
Tillage systems on annual crops in Brazil: figures from the 2006 Agricultural Census
}

\section{Sistemas de preparo de solo em lavouras temporárias no Brasil: números do Censo Agropecuário de 2006}

\author{
Rafael Fuentes Llanillo ${ }^{1 *}$; Tiago Santos Telles ${ }^{1}$; \\ Dimas Soares Júnior ${ }^{1}$; Tiago Pellini ${ }^{1}$
}

\begin{abstract}
Data on no-tillage in Brazil in the last 30 years have been based on estimates made by the Brazilian NoTillage and Irrigation Farmers' Federation (FEBRAPDP), using secondary data supplied by the Rural Extension Service of Rio Grande do Sul state (EMATER-RS/ASCAR), the Agricultural Research and Rural Extension Service of Santa Catarina state (EPAGRI), the Institute of Technical Assistance and Rural Extension of Paraná state (EMATER-PR), the Coordination of Integral Technical Assistance of São Paulo state (CATI-SP), the MS Foundation for Research and Diffusion of Agricultural Technologies (MS FOUNDATION) and the Brazilian Savanna No-tillage Farmers'Association (APDC). More reliable data on the use of no-tillage and other soil tillage systems for annual crops in Brazil were made available in 2009 after publication of the 2006 Agricultural Census of the Brazilian Institute of Geography and Statistics (IBGE). While previous sources reported that the surface area of no-tillage in Brazil was 25.6 million hectares (Mha) in 2006, the present study, based on special tabulations presented by the 2006 Agricultural Census, indicates that no-tillage was used on approximately 17.8 Mha of annual crops. Furthermore, the 2006 Agricultural Census reported that minimum tillage was used on 3.8 Mha, a combination of minimum and conventional tillage was used on 3.1 Mha and that conventional tillage was used on 11.8 Mha, amounting to a national total of 36.6 Mha of annual crops.
\end{abstract}

Key words: No-tillage, minimum tillage, conventional tillage, conservation agriculture

\section{Resumo}

As informações sobre a área em plantio direto no Brasil nos últimos 30 anos foram baseadas exclusivamente em estimativas realizadas pela Federação Brasileira de Plantio Direto e Irrigação (FEBRAPDP), utilizando dados secundários da EMATER-RS/ASCAR, da Empresa de Pesquisa Agropecuária e Extensão Rural de Santa Catarina (EPAGRI), do Instituto Paranaense de Assistência Técnica e Extensão Rural (EMATER-PR), da Coordenadoria de Assistência Técnica Integral (CATISP), da FUNDAÇÃO MS e da Associação de Plantio Direto no Cerrado (APDC). No entanto, com a publicação do Censo Agropecuário de 2006, do Instituto Brasileiro de Geografia e Estatística (IBGE), em 2009, informações mais precisas foram disponibilizadas sobre a utilização desse sistema e de outros tipos de preparo de solo nas lavouras temporárias no Brasil. Enquanto a estimativa dava conta da existência de 25,6 milhões de hectares de plantio direto na palha no Brasil em 2006, o presente estudo indica que, para o mesmo ano, de acordo com tabulações avançadas do Censo Agropecuário, tal área era de 17,8 milhões de ha. Ainda pelo Censo Agropecuário 2006, foram totalizados 3,8 milhões de ha em cultivo mínimo, 3,1 milhões de ha em sistemas mistos de cultivo mínimo e preparo convencional e 11,8 milhões de ha em preparo convencional, nos 36,6 milhões de ha de lavouras temporárias no país.

Palavras-chave: Plantio direto, cultivo mínimo, preparo convencional, agricultura conservacionista

\footnotetext{
${ }^{1}$ Pesquisadores, Área de Socioeconomia, Instituto Agronômico do Paraná, IAPAR, Londrina, PR, Brasil. PR. E-mail: rfuentes@ iapar.br; telles@iapar.br; dimasjr@iapar.br; tpellini@iapar.br

*Author for correspondence
} 
During the 1970s, Brazil experienced rapid growth in area of land covered by annual crops (AC), consistent with changes that accompanied the Green Revolution, and this has radically altered soil management practices as traditional tillage techniques have been replaced with mechanized processes ${ }^{2}$. Traditional tillage consisted of plowing or harrowing as a primary preparation step, followed by use of leveling harrows as a secondary stage of preparation. Although tilling is effective to some extent in helping to control weeds, it results in pulverization of the surface soil and formation of a sowing bed. This pulverization causes soil compaction, also known as a "plough pan" or "harrow pan", which leads to rainfall losses of soil, organic matter and nutrients, creating erosion furrows, siltation of watercourses and deterioration of yield capacity of the land. Conventional tillage is reported to lead to soil losses of over $20 \mathrm{t} \mathrm{ha}^{-1}$ year $^{-1}$ (LOMBARDI NETO; PASTANA, 1972; BENATTI; BERTONI; MOREIRA, 1977; DECHEN; LOMBARDI NETO; CASTRO, 1981; ELTZ et al., 1984; DERPSCH et al., 1991; TELLES; GUIMARÃES; DECHEN, 2011).

In the 1970s, southern Brazil experienced major soil erosion that further worsened in the early 1980s. These events were followed by mitigation measures implemented primarily by pioneer farmers, which were further supported by institutions (mainly government-based) linked to agriculture. In fact, the use of soil conservation practices became mandatory for farmers to be eligible for agricultural loans. During this period, two forms of soil tillage were developed to tackle the problem of soil erosion: minimum tillage (MT), using low-impact soil-tillage practices such as chisel plowing; and

\footnotetext{
${ }^{2}$ Soil tillage aims to develop cultivation and improve water absorption and retention, controlling encroaching plants, improving biological activity and aerating the soil. Incorrect soil tillage can compromise the development of plant root systems, increase the risk of rapid inundation of plants after rain and allow a compact layer of soil to form. Soil management practices include conventional tillage, reducedtillage (minimum tillage), direct drilling and no-tillage (KÖLLER, 2003).
}

no-tillage $(\mathrm{NT})^{3}$, considered the most innovative system, which allowed sowing directly over residues from the previous crop without other soil disturbance.

No-tillage was formally initiated in Brazil in 1972 in Rolândia, a municipality of northern Paraná State, by its pioneer farmer Herbert Bartz, and by others in ensuing years. This initiative rapidly involved research, agricultural equipment and supplies industries and rural extension service. The NT emerged as the most important means of fighting the major problem of soil erosion caused by the expansion of mechanized production of soybean and wheat (BOLLIGER et al., 2006). Technological aspects of NT were studied during the late 1970s and throughout the 1980s, including appropriate seeders for sowing over straw and development of herbicides and cover crops for controlling weeds, which were the major constraints to this practice. In the late 1980s and early 1990s, the NT system was adapted to the Brazilian Savanna region and to small-scale farms based on draft animal power.

At the same time, integrated soil and waterconservation management programs were implemented by federal and state institutions, some of which were supported by World Bank loans. These programs encouraged the use of MT with chisel plowing and NT with direct drilling over the straw in addition to mechanical practices such as terracing and contour farming. Furthermore, the conservation programs promoted soil-correction methods, green manures and cover crops, recovery

\footnotetext{
${ }^{3}$ The first-mentioned studies on no-tillage were carried out in the 1940s at Rothamsted Experimental Station, England; these studies verified that soil tillage was not necessary because there was no competition from weeds (KORONKA, 1973). To implement this approach, the Imperial Chemical Industries (ICI) began to market paraquat in 1961, an herbicide that been discovered six years earlier. This allowed the first studies and groundwork in straw formation, a strong foundation and driver for the use of no-tillage (COUGHENOUR, 2003). The term was derived from the concept of "zero tillage", "notillage", or "direct drilling"; the English and North Americans were the first to mechanize the technique, planting seeds or seedlings with minimum soil interference and retaining coverage of plant detritus (JONES et al., 1968; BAEUMER; BAKERMANS, 1974).
} 
and protection of freshwater sources and springs, road maintenance, water barriers and gully repair.

In the mid-1990s, the area of land under NT reached one million hectares (Mha), and has since increased and has overtaken MT as an agricultural conservation system. On the basis of the estimates of the Brazilian No-Tillage and Irrigation Farmers' Federation (FEBRAPDP, 2013), NT was practiced on up to 25.5 Mha in Brazil by 2006. On the basis of estimates by Derpsch et al. (2010), NT has been implemented on approximately 116 Mha of agricultural land worldwide, 26.5 of which are in the USA, 25.5 in Brazil, 20 in Argentina, 17 in Australia, 13.5 in Canada, 2.4 in Paraguay, 1.3 in China, 1.2 in Kazakhstan, and the remaining 2.6 Mha in other countries. The United Nations Food and Agriculture Organization (FAO) has utilized NT, together with Brazilian machinery, to disseminate the use of conservation agriculture in Africa, Central Asia, China, North Korea, Central America and the Caribbean.

The expansion of NT in Brazil reached such a magnitude that in 2006, for the first time, the Agricultural Census conducted by the Brazilian Institute of Geography and Statistics (IBGE) carried out a survey on the amount of area with NT in straw (IBGE, 2009), in its section on soil tillage practices in $\mathrm{AC}$.

The objective of the present study was to present, analyze and discuss the types of soil tillage used in annual cropping systems in Brazil following the release of the 2006 Agricultural Census data by IBGE. Data used in the study were obtained from special tabulations of the 2006 Agricultural Census ${ }^{4}$ requested from the IBGE.

The 2006 Agricultural Census questionnaire asked interviewees which of the following four soil

\footnotetext{
4 The special tabulations of the 2006 Agricultural Census are the product of multiple variables, which were modeled and formatted according to the research demands. These tabulations were directly requested from the IBGE, in accordance with institutional procedures. It is not public information nor does it constitute a current publication.
}

management practices were used on their farm year round: none/no preparation ${ }^{5}$; conventional tillage; minimum tillage; and no-tillage in straw. More than one option could be indicated in cases of soil tillage combinations, with additional information then being requested regarding the size of the NT area.

The 2006 Agricultural Census handbook describes each type of soil tillage as: (a) conventional tillage (CT) or deep harrowing, a mode of soil tillage involving plowing followed by harrowing with leveling harrow, disc plows or heavy discs and another phase of harrowing with leveling harrow; (b) MT, soil tillage characterized by reduced equipment use, usually by harrow leveling and then scarification and plowing, which inverts the soil and improves drainage and physical conditions; and (c) NT in straw, which involves small open furrows with straw cover and without the need for surface plowing or harrowing, retaining previous crop residues in the soil (IBGE, 2009).

Data on cultivated area were only available for NT, not for CT or MT. To fill this gap, it was used data on $\mathrm{AC}$, which represents almost the entire surface area of tilled land (IBGE, 2009). Therefore, it was possible to determine the area of $\mathrm{AC}$ according to four tillage categories: CT only, MT only, NT only, and a combination of soil tillage practices (mixed preparation). It was also possible to distinguish the area of AC holdings that used NT exclusively from areas that used NT in combination with other practices. To differentiate the AC data according to soil tillage, the calculated NT area was subtracted from the area in which mixed preparation (CT, MT, and NT) was used, and then was added to the non-declared AC area in NT on farm holdings that reported exclusive use of NT. This resulted in a new category, referred to as the mixed CT and MT method. For areas using only CT or MT, data supplied by the IBGE were used.

\footnotetext{
In cases in which the producer does not carry out soil preparation and the crop, if any, is cultivated using spaced planting spots, or in greenhouses using containers, or when soil is not used in cultivation, such as that in hydroponics (IBGE, 2009).
} 
The results presented in Table 1 show that NT in straw was the prevailing soil management practice, occupying close to 17.9 Mha, which represented approximately $49 \%$ of the total AC area (36.6 Mha) in Brazil in 2006. In addition, about 3.8 Mha used MT, whereas mixed CT and MT methods were reported for 3.2 Mha, representing $10.6 \%$ and $8.6 \%$ of AC, respectively. Thus, CT was used on approximately $11.8 \mathrm{Mha}(32.2 \%)$ of the $\mathrm{AC}$ area.

Although these figures still guarantee a prominent position for Brazil in terms of NT adoption at the global scale, these numbers conflict with estimates that suggested approximately 25.5 Mha were under NT in Brazil (DERPSCH et al., 2010; FEBRAPDP, 2013). Even if the area using MT was added to that of NT, the resulting 21.7 Mha (54.9\% of AC) is still considerably lower than the referenced estimates. The only approach that would result in consistency between the findings of the Agricultural Census and other estimates would be to consider the total NT, MT and mixed CT and MT areas as conservation agriculture. This would result in approximately 24.8 Mha $(67.8 \%$ of AC).

Interpretation of the 2006 Agricultural Census data according to regions and federative units of Brazil indicates that the Southern Region utilized the greatest total area of NT (over 8.5 Mha) as well as the highest relative percentage of NT, reaching $68.2 \%$ of 12.5 Mha of regional AC area. Paraná state included the highest relative percentage of NT in straw, with $73.7 \%$ of AC. In southern Brazil, MT was practiced least, estimated as 0.9 Mha (6.9\% of AC), followed by the mixed CT and MT methods ( 0.8 Mha, $6.3 \%$ of AC). The area of NT, MT and mixed MT and CT totaled 10.2 Mha of conservation agriculture (81.4\% of AC), compared to 2.3 Mha of CT (18.6\% of AC) in southern Brazil. The cultivation of crops such as sugar cane, beans and tobacco, is responsible for the significant role of $\mathrm{CT}$ in southern Brazil; in addition to technical constraints on changing soil tillage methods for these crops, restrictive landscape conditions complicate the use of equipment and agricultural machinery in this region.

In 2006, the central-western region held the second-largest area of NT in Brazil, close to 6.5 Mha representing $65.4 \%$ of the 10 Mha of $\mathrm{AC}$ in this region. Mato Grosso state stood out in terms of total NT area (3.3 Mha), while in relative terms the Federal District used NT on $77.0 \%$ of AC, although this represented only 67,000 hectares. Use of MT and mixed MT and CT in the centralwestern region occurred on $6.9 \%$ and $6.3 \%$ of the total AC area, respectively. The total area on which NT, MT and mixed MT and CT was practiced in the central-western region was estimated as 8.1 Mha of conservation agriculture $(81.2 \%$ of $\mathrm{AC})$.

No-tillage was dominant in the southern and central-western regions, at $68.2 \%$ and $65.4 \%$ of $\mathrm{AC}$, respectively, while $\mathrm{MT}$ and mixed $\mathrm{MT}$ and $\mathrm{CT}$ were used on $13.2 \%$ and $15.7 \%$ of $\mathrm{AC}$, respectively. In 2006 , CT only was used on $18.6 \%$ and $18.8 \%$ of the $\mathrm{AC}$ in these two regions. The use of light plowing after maize harvesting and the traditional model of sugar cane cultivation may have been the elements that largely influenced the use of MT and CT.

No-tillage was not as dominant in the other Brazilian regions and federative units as it was in the southern and central-western regions in 2006. The southeastern region stood out for its comparatively low level of NT adoption, with only $20.2 \%$ of AC. In São Paulo, an important agricultural state, only 472,000 hectares (11.0\% of AC) used NT. Conventional tillage dominated the southeastern region, covering 4.2 Mha (61.0\% of regional AC). This phenomenon is clearly linked to sugar cane farming, which requires heavy soil tillage and straw burning before harvest. The sum of NT, MT and mixed MT and CT areas, regarded as conservation agriculture, totaled $2.7 \mathrm{Mha}(39.0 \%)$ of the AC area in southeastern Brazil. 
Table 1. Total area in hectares (ha) and relative percentage of each type of soil tillage in area covered by annual crops (AC) in Brazil, according to macro-regions and Federative Units (FU), in 2006.

\begin{tabular}{|c|c|c|c|c|c|c|c|c|c|c|}
\hline \multirow[t]{2}{*}{ Region/FU } & \multicolumn{2}{|l|}{ CT } & \multicolumn{2}{|l|}{ MT } & \multicolumn{2}{|c|}{ Mixed } & \multicolumn{2}{|l|}{ NT } & \multicolumn{2}{|c|}{ Total } \\
\hline & ha & $\%$ & ha & $\%$ & ha & $\%$ & ha & $\%$ & ha & $\%$ \\
\hline Southern Region & $2,327,981$ & 18.6 & 860,972 & 6.9 & 792,202 & 6.3 & $8,550,269$ & 68.2 & $12,531,423$ & 100.0 \\
\hline Paraná & 851,179 & 16.9 & 257,590 & 5.1 & 217,096 & 4.3 & $3,707,074$ & 73.7 & $5,032,939$ & 100.0 \\
\hline Santa Catarina & 355,664 & 26.5 & 98,554 & 7.3 & 129,083 & 9.6 & 757,879 & 56.5 & $1,341,180$ & 100.0 \\
\hline Rio Grande do Sul & $1,121,139$ & 18.2 & 504,827 & 8.2 & 446,022 & 7.2 & $4,085,316$ & 66.3 & $6,157,304$ & 100.0 \\
\hline Central-Western Region & $1,876,756$ & 18.8 & 689,019 & 6.9 & 881,777 & 8.8 & $6,523,624$ & 65.4 & $9,971,176$ & 100.0 \\
\hline Distrito Federal & 9,066 & 10.4 & 5,576 & 6.4 & 5,177 & 6.0 & 67,186 & 77.2 & 87,006 & 100.0 \\
\hline Goiás & 666,492 & 23.1 & 129,767 & 4.5 & 168,486 & 5.8 & $1,916,092$ & 66.5 & $2,880,838$ & 100.0 \\
\hline MatoGrosso do Sul & 367,026 & 19.9 & 87,584 & 4.8 & 134,391 & 7.3 & $1,253,132$ & 68.0 & $1,842,134$ & 100.0 \\
\hline MatoGrosso & 834,172 & 16.2 & 466,091 & 9.0 & 573,722 & 11.1 & $3,287,213$ & 63.7 & $5,161,198$ & 100.0 \\
\hline Southeastern Region & $4,236,328$ & 61.0 & 640,817 & 9.2 & 662,030 & 9.5 & $1,406,496$ & 20.2 & $6,945,671$ & 100.0 \\
\hline Espírito Santo & 93,365 & 75.9 & 20,251 & 16.5 & 6,118 & 5.0 & 3,219 & 2.6 & 122,953 & 100.0 \\
\hline Minas Gerais & 912,108 & 38.3 & 326,393 & 13.7 & 215,023 & 9.0 & 927,971 & 39.0 & $2,381,495$ & 100.0 \\
\hline Rio de Janeiro & 120,120 & 79.2 & 24,012 & 15.8 & 4,013 & 2.6 & 3,526 & 2.3 & 151,671 & 100.0 \\
\hline São Paulo & $3,110,736$ & 72.5 & 270,161 & 6.3 & 436,876 & 10.2 & 471,779 & 11.0 & $4,289,552$ & 100.0 \\
\hline Northeastern Region & $3,073,127$ & 47.8 & $1,414,380$ & 22.0 & 767,452 & 11.9 & $1,170,724$ & 18.2 & $6,425,683$ & 100.0 \\
\hline Alagoas & 248,387 & 46.7 & 110,586 & 20.8 & 157,058 & 29.5 & 16,105 & 3.0 & 532,137 & 100.0 \\
\hline Bahia & $1,186,318$ & 49.8 & 286,107 & 12.0 & 274,477 & 11.5 & 636,251 & 26.7 & $2,383,154$ & 100.0 \\
\hline Ceará & 237,537 & 41.0 & 248,881 & 43.0 & 27,978 & 4.8 & 64,282 & 11.1 & 578,678 & 100.0 \\
\hline Maranhão & 151,967 & 21.5 & 121,280 & 17.1 & 136,365 & 19.3 & 298,166 & 42.1 & 707,779 & 100.0 \\
\hline Paraíba & 119,060 & 38.6 & 144,367 & 46.8 & 36,469 & 11.8 & 8,870 & 2.9 & 308,766 & 100.0 \\
\hline Pernambuco & 593,480 & 67.0 & 202,489 & 22.9 & 56,181 & 6.3 & 33,343 & 3.8 & 885,492 & 100.0 \\
\hline Piauí & 344,622 & 51.9 & 150,708 & 22.7 & 59,407 & 8.9 & 109,112 & 16.4 & 663,848 & 100.0 \\
\hline Rio Grande do Norte & 124,878 & 49.4 & 112,140 & 44.4 & 12,810 & 5.1 & 2,747 & 1.1 & 252,575 & 100.0 \\
\hline Sergipe & 66,877 & 59.1 & 37,822 & 33.4 & 6,707 & 5.9 & 1,848 & 1.6 & 113,254 & 100.0 \\
\hline Northern Region & 270,021 & 37.1 & 178,306 & 24.5 & 58,293 & 8.0 & 220,661 & 30.3 & 727,281 & 100.0 \\
\hline Acre & 7,642 & 45.3 & 2,351 & 13.9 & 1,018 & 6.0 & 5,851 & 34.7 & 16,862 & 100.0 \\
\hline Amapá & 5,212 & 82.4 & 697 & 11.0 & 171 & 2.7 & 249 & 3.9 & 6,329 & 100.0 \\
\hline Amazonas & 13,832 & 45.6 & 5,917 & 19.5 & 667 & 2.2 & 9,928 & 32.7 & 30,343 & 100.0 \\
\hline Pará & 81,440 & 38.9 & 64,149 & 30.7 & 15,934 & 7.6 & 47,749 & 22.8 & 209,272 & 100.0 \\
\hline Rondônia & 39,569 & 34.6 & 22,893 & 20.0 & 9,889 & 8.7 & 41,924 & 36.7 & 114,275 & 100.0 \\
\hline Roraima & 15,972 & 55.0 & 2,669 & 9.2 & 2,706 & 9.3 & 7,687 & 26.5 & 29,034 & 100.0 \\
\hline Tocantins & 106,354 & 33.1 & 79,630 & 24.8 & 27,909 & 8.7 & 107,274 & 33.4 & 321,166 & 100.0 \\
\hline Brazil & $11,784,213$ & 32.2 & $3,783,494$ & 10.3 & $3,161,754$ & 8.6 & $17,871,773$ & 48.8 & $36,601,234$ & 100.0 \\
\hline
\end{tabular}

Notes: FU, Federative Units of Brazil. CT, conventional tillage: a mode of soil tillage involving plowing followed by harrowing with leveling harrow, disc plows or heavy discs, and another phase of harrowing with leveling harrow. MT, minimum tillage: soil tillage characterized by reduced equipment use, usually by harrow leveling and then scarification and plowing, which inverts the soil and improves drainage and physical conditions. Mixed: combination of soil tillage practices. NT, no-tillage in straw: involves small open furrows with straw cover and without the need for surface plowing or harrowing, retaining previous crop residues in the soil.

Source: 2006 Agricultural Census of the Brazilian Institute of Geography and Statistics (IBGE), special tabulations. 
Northeastern Brazil also presented a low level of NT adoption, with 1.17 Mha (18.2\%) of 6.4 Mha of regional AC. However, there was prominent use of NT in Bahia state (636,000 hectares, $26.7 \%$ of AC), Maranhão state $(298,000$ hectares, $42.1 \%$ of AC), and Piauí state (109,000 hectares, $16.4 \%$ of AC). These federative units, together with Tocantins state, form the most recent Brazilian agricultural frontier: the MATOPIBA. Conventional tillage was predominant in the Northeastern region, comprising 3.07 Mha (47.8\%) of regional $\mathrm{AC}$, and ranging from a minimum of $38.6 \%$ of AC in Paraíba state to $67.0 \%$ in Pernambuco state. The only exception was Maranhão, in which NT was dominant. In the northeast, MT occupied 1.4 Mha (22.0\%) of regional AC. Thus, there was a balance between CT and MT in this region in 2006. This observation suggests that the conservation agriculture strategy for this region of Brazil, which comprises the country's semi-arid area, is based on MT, possibly due to the difficulty of maintaining permanent straw cover in dryland agriculture and because soil tilling has been used in all annual crops, even if at a reduced levels.

In 2006, the northern region of Brazil had the smallest area of AC, estimated as approximately 727,000 hectares (or 2.0\%) of total Brazilian AC. This region showed a balance between CT (approximately 270,000 hectares, 37.1\% of AC), NT $(221,000$ hectares, $30.3 \%$ of AC) and PM (178,000 hectares, $24.5 \%$ of AC). Tocantins state contained $44.2 \%$ of the region's total AC, estimated as 321,000 hectares. Together, Amazonas, Amapá, Roraima and Acre states contained 82,000 hectares of $\mathrm{AC}$, equivalent to $11.4 \%$ of the regional $\mathrm{AC}$.

In brief, this research emphasized the substantial growth in adoption of conservation agriculture methods in Brazil, which as of 2006 had reduced conventional tillage to only $32.3 \%$ of AC. Notillage was used on $48.8 \%$ of Brazilian AC area in 2006. In addition, MT and mixed methods, which can produce incremental increases in soil quality and lead to agricultural sustainability, were used in almost $18.9 \%$ of the AC area.
The introduction of soil tillage as a subject in the 2006 Agricultural Census by IBGE resulted in collection of valuable information on soil conservation practices in Brazil. The methods of collecting soil conservation data can be refined for the next Agricultural Census, which will be undertaken in 2015. Such information could provide additional details that would enable improved classification and differentiation of soil tillage practices in Brazilian agriculture. Although there were some limitations to the soil tillage data provided by the 2006 Agricultural Census, the information included in this Census is highly valuable and more precise than estimates published in the recent past.

\section{Acknowledgments}

The authors would like to express their gratitude to the IBGE's Agricultural Census Directorate and to Mr. Antonio Carlos Simões Florido for the special tabulations.

\section{References}

BAEUMER, K.; BAKERMANS, W. A. P. Zero-Tillage. Advances in Agronomy, San Diego, v. 25, p. 77-123, 1974.

BENATTI, J. R. R.; BERTONI, J.; MOREIRA, C. A. Perdas por erosão em plantio direto e convencional de milho em dois solos de São Paulo. Revista Brasileira de Ciência do Solo, Campinas, v. 1, n. 2, p. 121-123, 1977.

BOLLIGER, A.; MAGID, J.; AMADO, J. C. T.; SKÓRA NETO, F.; RIBEIRO, M. F. S.; CALEGARI, A.; RALISCH, R.; NEERGAARD, A. Taking stock of the Brazilian "Zero Till Revolution:" a review of landmark research and farmers' practice. Advances in Agronomy, San Diego, v. 91, p. 47-110, 2006.

COUGHENOUR, C. M. Innovating conservation agriculture: the case of no-till cropping. Rural Sociology, Hoboken, v. 68, n. 2, p. 278-304, 2003.

DECHEN, S. C. F.; LOMBARDI NETO, F.; CASTRO, O. M. Gramíneas e leguminosas e seus restos culturais no controle da erosão em Latossolo Roxo. Revista Brasileira de Ciência do Solo, Campinas, v. 5, n. 2, p. 133-137, 1981. 
DERPSCH， R.; FRIEDRICH， T.; KASSAM， A.; HONGWEN, L. Current status of adoption of no-till farming in the world and some of its main benefits. International Journal of Agricultural and Biological Engineering, Beijing, v. 3, n. 1, p. 1-25, 2010.

DERPSCH, R.; ROTH, C. H.; SIDIRAS, N.; KÖPKE, U. Controle da erosão no Paraná, Brasil: sistemas de cobertura do solo, plantio direto e preparo conservacionista do solo. Eschborn, GTZ/IAPAR, 1991. $272 \mathrm{p}$.

ELTZ, F. L. F.; CASSOL, E. A.; GUERRA, M.; ABRÃO, P. U. R. Perdas de solo e água por erosão em diferentes sistemas de manejo e coberturas vegetais em solo São Pedro (Podzólico Vermelho Amarelo) sob chuva natural. Revista Brasileira de Ciência do Solo, Campinas, v. 8, n. 2, p. 245-249, 1984.

FEDERAÇÃO BRASILEIRA DE PLANTIO DIRETO NA PALHA - FEBRAPDP. Área de PD. Área de PD. Evolução da área de plantio direto no Brasil. 2013. Available at: <www.febrapdp.org.br>. Accessed at: 4 mar. 2013.
INSTITUTO BRASILEIRO DE GEOGRAFIA E ESTATÍSTICA - IBGE. Censo agropecuário: 2006. Rio de Janeiro: IBGE, 2009. 777 p.

JONES, J. N.; MOODY, J. E.; SHEAR, G. M.; MOSCHLER, W. W.; LILLARD, J. H. The No-Tillage system for corn (Zea mays L.). Agronomy Journal, Madison, v. 60, n. 1, p. 17-20, 1968.

KÖLLER, K. Techniques of soil tillage. In: TITE, A. E. Tillage in agroecosystems. Boca Raton: CRC Press, 2003. p. 1-25.

KORONKA, P. Machinery development for direct drilling. Outlook on Agriculture, Elmsford, v. 7, n. 4, p. 190-195, 1973.

LOMBARDI NETO, F.; PASTANA, F. I. Relação chuvaperdas por erosão. Bragantia, Campinas, v. 31, n. 19, p. 227-234, 1972.

TELLES, T. S.; GUIMARÃES, M. F.; DECHEN, S. C. F. The costs of soil erosion. Revista Brasileira de Ciência do Solo, Viçosa, v. 35, n. 2, p. 287-298, 2011. 
